\title{
MUSEOLOGY AND MONUMENT PROTECTION IN THE DISCOURSE OF FRENCH NATIONAL IDENTITY
}

\section{Oleksii Prysiazhniuk}

\section{INTRODUCTION}

Even in the Renaissance, French kings and aristocrats began to collect ancient antiquities. For example, King Henry II received, as a gift from Pope Paul IV, in addition to bronze copies of famous antique statues, the statue "Diana with a doe" with a hint of his metressa Diana de Poitiers. Later, King Henry IV ordered the Antique Hall in the Louvre to be decorated for this statue. King Louis XIV sailed through "Germanicus" and "Jason" from Montalto's villa to decorate Versailles. However, ancient sculptures and artifacts were scattered, serving only as decoration of the royal palaces: Fontainebleau, SaintCloud, Versailles. The city palaces of the Louvre and Tuileries, of course, contained a considerable number of ancient statues, the Cardinal's Palace (Palais Royal) and the Montmorency Palace competed with them. Interest, however, was caused only by ancient monuments and this entire period can be classified as a stage of "collecting". In general, in France, interest in collecting arises in parallel with similar processes in other European countries and quickly, by the beginning of the 16th century, became a noticeable phenomenon in the life of French society. Collecting collections turns into a phenomenon that covers literally all segments of the population. Belonging to the elite does not mean the obligatory presence of a collection, but the collection itself allows even a non-ordinary person to be accepted into the circle of amateur favorites.

During this period, collection reached its special peak in the 16th18th centuries, when even a special name appeared for collections the cabinet. The composition of the cabinets was determined not only by the degree of wealth and education of their owners, but also by general trends in the development of this phenomenon in France and in Europe. Initially, the cabinets fully met the Renaissance idea of the 
possibility of imitating nature and its knowledge on the basis of a specially created microworld. The composition of the cabinets exhausts the composition of the universe, objects should have been concentrated here, characterizing all the processes taking place in the world.

The level of development of science did not always allow compiling collections on a truly scientific basis. However, the XVII century - the first century of science in the modern sense of this concept - has brought significant changes both in the person's knowledge of the world and in the presentation of this world in classrooms.

At the end of the XVII - XVIII centuries, collections became more specialized in profile, more and more often they included disciplines of the natural science cycle. This process of changing the topic of classrooms was reflected in its own way by the famous "Encyclopedia, or Explanatory Dictionary of Sciences, Arts and Crafts" - the term "cabinet" has only a few lines in it, while an extensive article is devoted to the study of natural history, describing in detail the composition of such a cabinet ${ }^{1}$.

In the 18th century, shifts of a different nature also took place many museum features began to take shape within individual collections. First of all, we mean the design of the principle of accessibility of collections for the public, based on the ideas of the Enlightenment. These representations imply the educational purpose of collections of exemplary works for artists (as role models) and for amateurs (as objects of study). That is why in the "Encyclopedia, or Explanatory Dictionary of Sciences, Arts and Crafts", the creation of the museum was associated with the opening of the royal collection, which included recognized masterpieces of European art. Many collections are open to visitors in the 18th century. These are meetings at drawing academies and schools, private rooms, a royal office, open for visits at the Luxembourg Palace in 1750-1779. However - and this is one of the features of the development of museum business

\footnotetext{
${ }^{1}$ Kuklinova I. A. (2001) Muzei Frantsii XIV - XIX vekov [Museums of France of the XIV - XIX centuries]. St. Petersburg: SPbGUKI. P. 104.
} 
in France - the museum based on the royal cabinet was not opened until the era of the French Revolution, although in the XVIII century there was an active process of creating museums on the basis of royal and princely collections. The formation of museum features in the framework of cabinets during this period is also expressed in posing questions of the significance of objects as historical sources. It was in the 18th century that the first attempts to perpetuate local ancient and modern history in the collections of Arles, Dijon, Toulouse were made. For the first time, the restoration of monuments of the past is being addressed and methods for organizing the exposition are being developed.

Thus, the idea of museums in France was formed throughout the eighteenth century, and the French Revolution was the impetus for the creation in France of the first European network of museums.

\section{Formation of the legislative framework}

The legislative protection of monuments and its cultural heritage in France began in the years of the revolution. The French revolutionary government, by decree of the National Constituent Assembly of 1790, banned the destruction of immovable and movable works of art in the former royal estates, buildings and apartments of emigrants.

"Decree of the Constituent Assembly on public education, on the protection of buildings that have become national property, as well as monuments, storage facilities, libraries, etc., located in Paris on October 13-19, 1790.

The National Assembly decided:

1. That it will deal with educational issues only after the Constitutional Committee, to which it has entrusted the broadest powers in this area, presents its opinion on this part of the constitution.

2. So that the learning process does not stop, the Assembly will ask the King to order the resumption of classes at various public schools this year, as usual, without changing, however, the requirements of the decree on the clergy of the clergy regarding seminaries.

3. The meeting instructs the directories of the departments to collect information on the state of the monuments, churches and 
buildings located on their territory, which have become national property, and by all means at their disposal to protect them. The collected information will be transferred to the Committee on Property Alienation.

4. The meeting instructs the municipality of Paris to show the same care for the numerous monuments of the same kind existing in this city, for the storage of charters, documents, papers and libraries. In order for oversight to be competent, the municipality must cooperate with elected members of various Academies".2.

However, two years later, the National Assembly, which took the reins of government and legislative initiative, allows and even prescribes the destruction of monuments that can remind of feudalism, and the destruction of everything that could revive the memories of the despotism of the royal power.

"Decree of the Legislative Assembly on the destruction of monuments evoking feudalism on August 14, 1792.

The National Assembly believes that the sacred principles of freedom and equality do not allow preserving the monuments erected in the glory of pride, prejudice and tyranny before the eyes of the French people.

The Assembly believes that, cast over the cannons, the bronze of these monuments will usefully serve the cause of protecting the homeland, and decrees the adoption of immediate measures.

By deciding on immediate action, the Assembly decrees the following:

Art. 1. All statues, bas-reliefs, inscriptions and other monuments made in bronze or in any other material, erected in public squares, in temples, gardens, parks and grounds, in buildings belonging to the nation, and even in those that were left in possession of the King, - all these monuments should be removed by the efforts of representatives of the communes, who will temporarily monitor their safety.

Art. 2. Representatives of the Commune of Paris under the supervision of the Minister of the Interior, two members of the

${ }^{2}$ Dokumenty istorii Velikoy frantsuzskoy revolyutsii (1990) [Documents of the history of the Great French Revolution]. T. 1. Moscow: MGU. P. 484-485. 
commission of armaments and two members of the commission of monuments must immediately transfer to the instrument all the items listed in Art. 1 and located in the city of Paris.

Art. 3. All sorts of monuments left over from feudalism and still located in churches, other public places, and even on the facades of private buildings, should be immediately destroyed by communes.

Art. 4. The Commission of Monuments is specifically instructed to monitor the preservation of those objects that are primarily of artistic value, and submit to the Legislative Corps a list of these objects for approval.

Art. 5. The Arms Commission must immediately submit a draft decree, according to which metal from monuments located within the borders of each commune of France, will usefully serve the cause of its protection"3.

A year later, the National Convention decides on the creation of the Museum of the Republic and the collection under its roof of all the most valuable bright works of art. "The decree on the organization of the museum in the premises of the Louvre (according to the report of A.-F. Serjan) July 27, 1793.

According to the reports of the committees of public education and monuments, the National Convention decides:

Art. 1. The Minister of the Interior will give the necessary orders to open the Museum of the Republic on 10 August this year in the gallery connecting the Louvre with the Palais Nacional.

Art. 2. The Minister must order that, under the supervision of Commissars for Monuments, paintings, statues, vases, valuable furniture, marble articles located in the premises of the monastery of small Augustinians, in former royal palaces, in other public buildings and national repositories, with the exception of those items that are currently stored in the castle of Versailles, in parks, in both Trianons and are protected in their department by special decree.

Art. 3. The minister must also order the transfer to the museum of antique paintings, statues and busts located in all former royal palaces,

${ }^{3}$ Dokumenty istorii Velikoy frantsuzskoy revolyutsii (1990) [Documents of the history of the Great French Revolution]. T. 1. Moscow: MGU. Pp. 484-485. 
in castles, gardens and parks owned by emigrants and in other national possessions",

The preparation of the decrees of the Convention for the Protection of Monuments and the organization of the Museum of the Republic was directed by Jacques-Louis David. In July 1793, he made a report at the Museum Vault Convention, where he spoke about general principles and the practical program of museum work. David said: "The museum is not at all a useless collection of luxury goods and vanity, serving only to satisfy curiosity. It is necessary for the museum to become a school of great importance... we need to reveal all the wealth in front of the life-giving eye of the people...",

For the first time for the general public, the doors of the museum opened on August 10, 1793.

Unfortunately, countless artistic treasures have perished as victims of blind fanaticism and a wild passion for destruction in the storms of the French Revolution. The revolutionary government, unable to create and consistently carry out the planned events, contributed little to the preservation of the huge cultural heritage from church buildings and palaces, which passed to it on the basis of the laws of secularization and emigration. Many decades passed, while freedom-loving Frenchmen stopped using medieval monuments of building art for barracks. So, for example, the papal palace in Avignon only in 1906 was freed from the functions of the barracks and carried out restoration.

A somewhat peculiar "merit" of creating a single new center for the storage of ancient heritage in France belongs to Napoleon Bonaparte. Following the example of Alexander the Great and combining the Egyptian expedition with a scientific expedition, he returned to the much less laudable custom of the Roman commanders, who used to plunder conquered countries and take art treasures stolen from them, to Rome. This example was portrayed in the imagination of a young

${ }^{4}$ Dokumenty istorii Velikoy frantsuzskoy revolyutsii (1990) [Documents of the history of the Great French Revolution]. T. 1. Moscow: MGU. Pp. 484-485.

${ }^{5}$ David Zh.-L. (1933) Rechi i pis'ma zhivopistsa Lui Davida [Speeches and Letters by the Painter Louis David]. Moscow; Leningrad: Isogiz. P. 186. 
winner back in 1796, when on June 23 he included paragraph VIII in the armistice in Bologna: "The pope will deliver to the French Republic a hundred paintings, busts, vases or statues of the choice of commissioners to be sent to France, among which will be a bronze bust of Junius Brutus and a marble bust of Mark Brutus, statues from the Capitol and five hundred manuscripts of the choice of the mentioned commissioners" ${ }^{\prime}$. A special reference to the busts of Caesar's killers is characteristic of the Republican. The pope vainly resisted, but this same cruel condition was included in the February 1797 treaty of Tolentino. Among the antique objects, the choice fell on the famous masterpieces of the Belvedere and its hall of muses. The Capitol has lost about a dozen of its best statues, among them the statues of the "Dying Gaul" and "The Boy Removing the Splinter". However, this was not limited to this: under more or less transparent pretexts, private collections were also included - a collection of the Duke of Braska, a relative of the pope, and mainly a rich collection of Cardinal Albani's villa. With revolutionary speed, all the antique artifacts stored in them were confiscated by the French and 517 items packed in 288 boxes were waiting on the Tiber for departure to Paris.

In November 1801, the 18th Brumaire of the year IX, just two years before the coup, the Central Museum was opened in the Louvre, which contained 117 monuments. About two years before this event, Ennio Quirino Visconti, who was briefly one of the five consuls of the Roman Republic, moved to Paris. For almost two decades, his scientific name has given brilliance to French museums and French archeology in general. It was he who compiled the first catalogs of the rapidly growing new museum. But the soul of the whole affair in this case, as in the Egyptian expedition, was Dominic Vivan Denon. He accompanied the army and chose works of art to be taken away. Florence was to give its Venus to the Medici, Venice of its four bronze horses from the church of St. Mark, Mantua, his famous busts of Euripides and Virgil, Verona of his Augustus Bevilacqua, Modena and

6 Mikhaelis A. (1913) Khudozhestvenno-Arkheologicheskie otkrytiya za 100 let [Artistic and archaeological discoveries for 100 years]. Moscow: Izdanie Imperatorskogo Moskovskogo Arkheologicheskogo Instituta Imeni Imperatora Nikolaya II. P. 23. 
Turin other objects. As it once was during the conversion of the Belvedere into the Pioclementine Museum, so now the number of antique halls grew in the Louvre ${ }^{7}$.

In 1806, it included the entire collection of antique objects of the Borghese, which Napoleon bought from his son-in-law Camillo Borghese. Soon, booty from Germany also joined: a praying boy from Berlin accompanying Victoria from the Brandenburg Gate, Athena from Kassel, the imaginary sarcophagus of Charlemagne from the cathedral in Aachen and other works, from 20 to 30 in total. In Vienna, D. Denon from 1809 the antique cabinet chose 24 subjects, among which only the alleged Ephesian sarcophagus with amazons was valuable; the gems of the imperial house were taken to Hungary on time.

The catalogs that often appeared in new editions made it possible to judge the expansion of the museum and its enrichment with selected art monuments. In 1815, the number of storage numbers reached 384 . Free access to the public, the creation of a workshop for making casts according to the originals of the museum, the preparation and publication of large publications with engravings - all this contributed to the increase in the benefits and fame of the Napoleon Museum and drowned the voices of those who put the museum in reproach is the way in which he mainly owed his origin ${ }^{8}$.

The collection of antique objects of the Napoleon Museum was entirely Roman in character. This included the most outstanding monuments of the Roman congregations, with the exception of the collection of Ludovisi; however, at the same time, there was not the fullness of the impression that Rome gave in its general antique character. The fact that the museum lacked the characteristic treasures of Naples deprived him of the advantage over Rome that he would

7 Zhebelev S. A. (1923) Vvedenie v arkheologiyu. Chast' II. Teoriya i praktika arkheologicheskogo znaniya [Introduction to archeology. Part II. Theory and practice of archaeological knowledge]. Petrograd: Nauka i shkola. Pp. 80-81.

${ }^{8}$ Mikhaelis A. (1913) Khudozhestvenno-Arkheologicheskie otkrytiya za 100 let [Artistic and archaeological discoveries for 100 years]. Moscow: Izdanie Imperatorskogo Moskovskogo Arkheologicheskogo Instituta Imeni Imperatora Nikolaya II. P. 25. 
have possessed those paintings and bronzes. The classical periods of Greek art were nevertheless presented in many more or less good copies, the Hellenistic era, and partly the Roman art in such beautiful originals that it becomes clear to E. Q. Visconti's view: antique art from Phidias to Hadrian seemed to be kept at the same height. It was a bold, albeit absurd attempt to replace the view of I. Winkelmann and his followers with another. The main classical idea of I. Winkelman, as you know, can be reduced to the thesis: art arises, develops and fades away in connection with the development of society. The great name of E. Q. Visconti obscured the historical absurdity, which consisted of such a view: six hundred years, full of the biggest changes in the lives of peoples, changes in geographical centers, changes in all politics and culture, but at the same time art is all at the same height, as if soaring above the clouds!

The Napoleon Museum was also the place of education of the then archaeologists. For them, E. Q. Visconti, the court archaeologist of Napoleon, was an indisputable authority, almost an oracle. In Germany, the forerunner of a similar anti-historical teaching was Friedrich Tiersch, who studied antique objects in Paris at that time.

With the fall of Napoleon in 1815, his ambitious creation collapsed. It was perfectly true that the one taken away by virtue of military law, was now returned to the previous owners in military law. Cardinal Secretary of State Consalvi was the representative of the interests of Rome. Wilhelm von Humboldt and the Duke of Wellington successfully tried to break the understandable resistance of the French commissars, mainly D. Denon. His property was returned to the Vatican almost entirely. The fact that the Tiber statue remained in Paris, while its twin statue of the Nile alone returned to the shores of the Tiber, was the result of petty court intrigue. Officially, Pope Pius VII presented the statue of the Tiber restored to the throne of Louis XVIII.

However, return shipping costs were so great that the papal government could only cover them with significant assistance from England. For the same reason, the heirs of Cardinal Albany were satisfied with the return of only four works from the stolen seventy; the rest were auctioned off in Paris and for the most part either returned to 
the Louvre or ended up in Munich Glyptothek. In the Capitol Museum, a special hall was reserved for the returning marbles, where they were grouped around the "Dying Gaul". Only the Borghese collection, as bought, remained in Paris and served as the core of the Louvre collection. The first catalog of this collection, the last work of E. Q. Visconti, published in 1817.

The Napoleon Museum was the last magnificent example of a collection of antiquities in the style of classicism. This museum is at the same time the crown and the end of the whole long revolutionary period in the history of France.

In 1810, a circular was sent out by the Minister of the Interior, Count de Montivalie, according to which the prefects were ordered to collect information about castles, abbeys (monasteries) and tombs that existed and still exist in the territory of their departments. Count Alexander the Labord, author of the work "Monuments of France, classified chronologically and examined in relation to historical facts and the study of art", the first volume of which was published in 1816, took part in its development.

It should also be noted that the entire Napoleonic Civil Code of 1804 had a huge impact on the entire subsequent cultural heritage protection system in France. He laid the foundations for the legislative protection of private property in France, denoting it, however, in article 552 very broadly: "The right of ownership of land extends to the surface and its bowels". In addition, "... on the surface of the earth, the owner can make plantings and constructions as he pleases", as well as "in the bowels of the earth he can undertake all kinds of constructions and excavations as he pleases, and extract from these excavations all the works that they can deliver, subject to the restrictions arising from laws and regulations..."

9 Kodeks Napoleona (1877) [Codex of Napoleon]. Sobranie grazhdanskikh zakonov guberniy Tsarstva Pol'skogo [Collection of Civil Laws of the Provinces of the Kingdom of Poland]. Pp. 159-160.

${ }^{10}$ Kodeks Napoleona (1877) [Codex of Napoleon]. Sobranie grazhdanskikh zakonov guberniy Tsarstva Pol'skogo [Collection of Civil Laws of the Provinces of the Kingdom of Poland]. Pp. 159-160. 
The Code also contains a very broad definition of the concept of "treasure" in Article 716: "The right of ownership of a treasure belongs to those who find it in their own estate; if the treasure is found in a strange estate, then one half belongs to the one who found it, and the other to the owner"11.

Article 552 of the Code defined the French national mentality and made it impossible for the state to assume full-fledged functions for the protection of monuments. Subsequent attempts to introduce state accounting and control of monuments, especially those that were privately owned, were perceived as a gross violation of the spirit of the Civil Code and the blood-fought traditions of French freedom ${ }^{12}$.

\section{Comprehension of the national past and design Basics of Monument Protection}

In the second quarter of the 19th century, the crisis of the value system experienced by France and the French, connected with the French revolution and subsequent events, was gradually resolved in a difficult way from idealizing the ancient past to understanding the national past ${ }^{13}$. At this time, romanticism, a powerful ideological and artistic movement, was a widespread reaction to classicism and the entire Enlightenment. An important feature of romanticism was the socalled "passionist reflection", expressed in the fascination with antiquity, its poetization, interest in folk life and folk literature, which thereby prompted a deep study of their national past. In addition, interest in "their" history and "their" monuments mainly religious, the

11 Kodeks Napoleona (1877) [Codex of Napoleon]. Sobranie grazhdanskikh zakonov guberniy Tsarstva Pol'skogo [Collection of Civil Laws of the Provinces of the Kingdom of Poland]. Pp. 159-160.

${ }^{12}$ Malyshev O. O. (2015) Arkheologhichne pravo Franciji: gheneza ta suchasnyj stan [Archeological law of France: genesis and current state]. Chasopys Kyjivsjkogho universytetu prava [Journal of the Kyiv University of Law]. P. 33-37; Malyshev O. O. (2018) Romansjka ta ghermansjka tradyciji arkheologhichnogho prava: sproba uzaghaljnennja [Romanesque and Germanic traditions of archaeological law: an attempt to generalize]. Pravova derzhava [Constitutional state]. № 29. P. 476-485.

${ }^{13}$ Lebedev G. S. (1992) Istoriya otechestvennoy arkheologii [History of Russian Archeology]. St. Petersburg: SPbGU. P. 69. 
organization of their protection and the development of restoration as an independent architectural movement were largely determined by France's internal political problems associated with a radical change in the socio-political face of society itself ${ }^{14}$.

The era of restoration (1815-1830) also shows examples of gross vandalism and unforgivable indifference of the government, so that Charles de Montalamber in 1830 could complain that over 15 years of the existence of the kingdom more monuments were destroyed in every department of France than during the whole revolutionary and imperial periods.

The government did not prevent privately owned buildings from being destroyed or converted into factories and workshops. It itself used monuments of church and secular architecture, like Mont SaintMichel and the papal palace in Avignon, for military purposes. Such people as Victor Hugo, Prosper Merimet, Charles de Montalamber, Jean-Baptiste Lasso, Eugene Emmanuel Viollet-le-Duc, combined with the efforts of learned societies and the French clergy not only among educated people, but also among the general public of the French population keen interest in monuments of past years. Victor Hugo's novel "Notre Dame de Paris" (1830) sounded a hymn to the glory of medieval architecture and a call to preserve its heritage. Initially, the cathedral, which was bred in the novel, became a subject of general attention. In the future, it was usually not about the construction of new buildings, but about the restoration of the masterpieces of the French Middle Ages, be it Saint Michel, Mont Saint Michel, the grand abbey in Vezle, the ancient fortifications of Carcassonne or the mountain castle of Roktaiad. The tireless Eugene Emmanuel Violletle-Duc had a hand in the implementation of almost all restoration projects, striving to bring even unfinished buildings in the Middle Ages to the last degree of completion.

${ }^{14}$ Rytsarev K. V. (1995) Nekotorye tendentsii v zapadnoevropeyskoy arkhitekturnoy restavratsii XIX veka [Some trends in the West European architectural restoration of the XIX century]. Restavratsiya i arkhitekturnaya arkheologiya: Novye materialy i issledovaniya [Restoration and Architectural Archeology: New Materials and Research]. Moscow. № 2. Pp. 4-5. 
Based on public opinion, interested in the development of history and art, the French government since the beginning of the thirties has been taking a number of measures aimed at protecting monuments.

The preservation of ancient monuments was institutionalized during the July monarchy, which is often defined as the "Guizot moment", named after the French historian and prominent politician Francois Guizot, who served as Minister of the Interior from August to November 1830 and Minister of Education from November 1832 to April 1837. For several years, from 1830 to 1837 , on his initiative, the main institutions of this centralized state system were created: General Inspectorate of Historical Monuments (1830), General in the history of France (1833), the Committee of historical and scientific works (1834), the Commission of historical monuments (1837). They were the organizational embodiment of the policies pursued by King Louis Philippe and François Guizot.

F. Guizot marked his coming to power with the reforms that he had previously proclaimed as a historian. He was worried about the search for foundations for national unity, the legitimization of the third estate, the demands put forward by new national history. He developed and implemented a program for the historical education of French society. "This is a serious disease of the nation," F. Guizot said, "to neglect the past and forget it"15. It was logical that the government of 1830, like the government of the First Empire, sought in respect of the past, in the cult of ancient France, guarantees of stability that were absent during their establishment. In the past, the medieval era was especially distinguished, when "the unity of society was based on the union of the monarchy with the third estate" ${ }^{16}$. National reconciliation was facilitated by the Catholic movement. In his return to beliefs, F. Guizot saw the benefits of maintaining social order and considered religion as

${ }^{15}$ Rytsarev K. V. (1995) Nekotorye tendentsii v zapadnoevropeyskoy arkhitekturnoy restavratsii XIX veka [Some trends in the West European architectural restoration of the XIX century]. Restavratsiya i arkhitekturnaya arkheologiya: Novye materialy i issledovaniya [Restoration and Architectural Archeology: New Materials and Research]. Moscow. № 2. P. 14.

${ }^{16}$ Bazen Zh. (1994) Istoriya istorii iskusstv: Ot Vazari do nashikh dney [History of Art History: From Vasari to the Present]. Moscow: Progress-Kul'tura. P. 217. 
a means of dispelling the moral suffering of the lower classes. This religious revival, which regarded the Gothic style as an expression of the Catholic faith itself, more than romanticism, contributed to the triumph of medieval architecture, which they began to actively study and preserve. It determined not only the construction of a large number of new churches in the "neo-Gothic style", but also the conservation and restoration of the ancients destroyed during the French Revolution and the Napoleonic Wars. It is no coincidence that the architect E.-E. Viollet-le-Duc, whose name marked a whole era in the restoration of historical monuments, considered the Gothic cathedral a symbol of the French nation ${ }^{17}$.

The beginning of the implementation of the "historical education program" F. Guizot can be considered the establishment on his initiative in October 1830 of the post of inspector general of historical monuments in the structure of the Ministry of Internal Affairs. The first general inspector of historical monuments was appointed politician, writer and archaeologist Louis Vite, who was in this post until 1834. Prosper Merimee, who replaced him, headed the general inspection of historical monuments from 1834 to 1860 . The functions that the general inspector should have performed formulated in a report by L. Vite at the end of his first official trip to the North of France in 1831: "To establish the existence and make a critical description of all the buildings of the kingdom, which either Athe, either by the nature of their architecture, or by the events of which they were witnesses, deserve the attention of an archaeologist, artist, historian, such is the first goal of the duties assigned to me. Secondly, I must take care of the preservation of these buildings, showing the government and local authorities ways to either prevent or stop their destruction" 18 .

${ }^{17}$ Bazen Zh. (1994) Istoriya istorii iskusstv: Ot Vazari do nashikh dney [History of Art History: From Vasari to the Present]. Moscow: Progress-Kul'tura. P. 217.

18 Nikolaeva N. S. (2008) Formirovanie gosudarstvennoy sistemy okhrany pamyatnikov vo vtoroy chetverti XIX veka (sravnitel'nyy analiz: Frantsiya i Rossiya) [Formation of the state system for the protection of monuments in the second quarter of the XIX century (comparative analysis: France and Russia)]. Izvestiya Rossiyskogo gosudarstvennogo pedagogicheskogo universiteta im A. I. Gertsena [Bulletin of the Russian State Pedagogical University named after A. I. Herzen]. № 80. P. 263. 
Naturally, one person was not able to complete these tasks. Therefore, when the post of inspector general was established, F. Guizot advocated the creation of local societies in the province by analogy with the Normandy Antiquarian Society, which, in his opinion, would most effectively preserve the monuments. In this connection, in French studies on the history of conservation activities, the formation of the Historical Monuments Service F. Guizot is seen as a response to the initiative of Count Arsis de Comon, who founded the Normandy Antiquarian Society in $1824^{19}$. F. Berse explains this reverence for F. Guizot with the vigor and fame of the founders of the Society, their significance in archaeological historiography. The activities of the Society of Antiquaries of Normandy, and directly of Arsis de Comon, played a significant role in organizing similar societies and conducting scientific meetings in the French provinces. In 1831, the Morini Antiquarian Society will be formed, in 1834 the West Antiquarian Society, and in 1836 the Picardy Antiquarian Society. Created in 1831, the Archaeological Society of the South of France will consider itself the successor to the Normandy Antiquarian Society. The idea of holding scientific meetings in France, successfully implemented by Arsis de Comon, was associated with a similar activity by Alexander Humbolt in Germany. The first scientific meeting was held in Caen in July 1833, the second in Poitiers in 1834. Two hundred people took part in their work. The result of such scientific meetings will be the creation in 1839 of the Provincial Institute ${ }^{20}$.

The success of Norman society led Arisis de Comon to the idea of creating a scientific society already on a national scale. In July 1834, he founded the French Archaeological Society, originally called the French Society for the Preservation and Description of Historical

${ }^{19}$ Bazen Zh. (1994) Istoriya istorii iskusstv: Ot Vazari do nashikh dney [History of Art History: From Vasari to the Present]. Moscow: Progress-Kul'tura. P. 94.

20 Nikolaeva N. S. (2008) Formirovanie gosudarstvennoy sistemy okhrany pamyatnikov vo vtoroy chetverti XIX veka (sravnitel'nyy analiz: Frantsiya i Rossiya) [Formation of the state system for the protection of monuments in the second quarter of the XIX century (comparative analysis: France and Russia)]. Izvestiya Rossiyskogo gosudarstvennogo pedagogicheskogo universiteta im A. I. Gertsena [Bulletin of the Russian State Pedagogical University named after A. I. Herzen]. № 80. P. 263. 
Monuments $^{21}$. The aim of the new Society was to study the monuments of France, compile their list and prevent their destruction or distortion by annoying restorations. Since its founding, the Society began annually conducting archaeological congresses in various provincial cities, reports on which were published in the "Bulletin monumental", and since 1845 they began to be issued as a separate publication. Thus, on the initiative of A. de Comon and with his direct participation in France, a powerful national network of scientific societies was formed.

A year earlier than the creation of the French Archaeological Society, the French History Society was formed, one of the founders of which was also F. Guizot, who was then Minister of Education. In January 1834, the charter of this Society was adopted, and work began on the study and publication of genuine sources related to national history. In July 1834, F. Guizot established the Committee of Historical and Scientific Works, the purpose of which was to study and publish unpublished documents on the history of France. In January 1835, another committee was created to facilitate the study and publication of unpublished documents on literature, philosophy, science and the arts relating to the general history of France - the Committee of Unpublished Monuments of Literature, Philosophy, Science and Art, considered in connection with the general history of France $^{22}$. This Committee united the main founders of the Service of Historical Monuments: V. Hugo, V. Cousin, L. Vite, O. Leprevo, S. Lenormann, P. Merimet, A. Lenoir, A.-N. Didrona. In 1837, the successor to F. Guizot, Minister of Education, Narsis-Achille de Salvandi, reorganized the Committee of Unpublished Monuments,

${ }^{21}$ Bazen Zh. (1994) Istoriya istorii iskusstv: Ot Vazari do nashikh dney [History of Art History: From Vasari to the Present]. Moscow: Progress-Kul'tura. P. 94.

22 Nikolaeva N. S. (2008) Formirovanie gosudarstvennoy sistemy okhrany pamyatnikov vo vtoroy chetverti XIX veka (sravnitel'nyy analiz: Frantsiya i Rossiya) [Formation of the state system for the protection of monuments in the second quarter of the XIX century (comparative analysis: France and Russia)]. Izvestiya Rossiyskogo gosudarstvennogo pedagogicheskogo universiteta im A. I. Gertsena [Bulletin of the Russian State Pedagogical University named after A. I. Herzen]. № 80. P. 263. 
dividing it into five sections in accordance with the five classes of the Institute of France. One of the sections was called the Committee of Arts and Monuments and was under the patronage of the Academy of Fine Arts. The tasks of this committee included the compilation of a list of monuments in France, concern for the preservation of destructible monuments, and assistance in organizing scientific work in the province ${ }^{23}$. At the time of the establishment of the Committee of Unpublished Monuments, F. Guizot appealed to scientific societies for cooperation, promising the provision of material assistance from the state, ensuring the exchange of publications and the annual publication of the most important scientific studies in a national journal ${ }^{24}$. In 1837 , the Commission of Historical Monuments was created in the structure of the Ministry of the Interior, whose functions also included identifying and studying monuments, compiling a list of them, ensuring their protection on the basis of subsidies specially allocated from the state, and directing restoration work ${ }^{25}$. Since its inception, the commission has relied on a previously formally established network of correspondents consisting of local scholars or scientific societies who were supposed to report on buildings in danger or on ongoing restorations. In twelve departments, these functions were performed by scientific societies. Where they were not, the prefects created commissions. Unfortunately, after ten years, the role of these

23 Nikolaeva N. S. (2008) Formirovanie gosudarstvennoy sistemy okhrany pamyatnikov vo vtoroy chetverti XIX veka (sravnitel'nyy analiz: Frantsiya i Rossiya) [Formation of the state system for the protection of monuments in the second quarter of the XIX century (comparative analysis: France and Russia)]. Izvestiya Rossiyskogo gosudarstvennogo pedagogicheskogo universiteta im A. I. Gertsena [Bulletin of the Russian State Pedagogical University named after A. I. Herzen]. № 80. P. 263.

24 Nikolaeva N. S. (2008) Formirovanie gosudarstvennoy sistemy okhrany pamyatnikov vo vtoroy chetverti XIX veka (sravnitel'nyy analiz: Frantsiya i Rossiya) [Formation of the state system for the protection of monuments in the second quarter of the XIX century (comparative analysis: France and Russia)]. Izvestiya Rossiyskogo gosudarstvennogo pedagogicheskogo universiteta im A. I. Gertsena [Bulletin of the Russian State Pedagogical University named after A. I. Herzen]. № 80. P. 264.

${ }^{25}$ Kuklinova I. A. (2001) Muzei Frantsii XIV - XIX vekov [Museums of France of the XIV - XIX centuries]. St. Petersburg: SPbGUKI. P. 76. 
provincial societies and correspondents was minimized ${ }^{26}$. In 1837 , following the tradition of the First Empire, a regular questionnaire was drawn up, consisting of 39 questions, according to which the prefects were to report on the most important monuments and monuments requiring urgent action to preserve them.

Based on their answers and with their help, the first monetary appropriations were determined. In 1840, the Commission of Historical Monuments published a list of monuments. Thus, with the establishment of the Commission of Historical Monuments, the formation of the state system for the protection of monuments, reflecting the intention of F. Guizot, aimed at inventorying all documents related to the spiritual and moral history of France, archives, libraries, monuments and works of art, was completed.

In this way the foundation was laid for an extensive classification system on which the French and later laws concerning monuments were built. A number of orders have established that the destruction or alteration of historical structures is permitted only with the permission of the Ministry of Education. However, due to the lack of legal authority, the measures taken by the government for the most part did not achieve their goal. Only the goodwill of the owners and the discretion of institutions independent of the Ministry of Education depended on the extent to which his orders were observed. Therefore, in 1875, the Minister of Education Henri-Alexander Vallon drafted a bill that concentrated all the care of the monuments in the hands of the Ministry of Education and supplied the Ministry with the necessary powers. Only on March 30, 1887, this project, after various upheavals and various alterations, was adopted by the Chamber of Deputies. And the export order contained in Section 18 of the Law was published on June 3, 1889. In general, the French law of March 30, 1897 owes its

26 Nikolaeva N. S. (2008) Formirovanie gosudarstvennoy sistemy okhrany pamyatnikov vo vtoroy chetverti XIX veka (sravnitel'nyy analiz: Frantsiya i Rossiya) [Formation of the state system for the protection of monuments in the second quarter of the XIX century (comparative analysis: France and Russia)]. Izvestiya Rossiyskogo gosudarstvennogo pedagogicheskogo universiteta im A. I. Gertsena [Bulletin of the Russian State Pedagogical University named after A. I. Herzen]. № 80. p. 264. 
occurrence mainly to representatives of art and science, as well as academic societies ${ }^{27}$.

The provisions of the first comprehensive law on March 30, 1887 were developed by the subsequent "Law on Historical Monuments" of December 31, 1913. An important innovation of this law was that it assumed a centralized record of not only state monuments, but also those cultural property that was privately owned. Also in this law, archaeological sites are characterized separately, although there are no special rules regarding archaeological excavations yet ${ }^{28}$.

\section{CONCLUSIONS}

The beginning of the process of forming a system of monument protection in France can be dated to the end of the 18th century - the adoption by the French revolutionary government of the decrees of the National Constituent Assembly, which nationalize all immovable and movable monuments, prohibit their destruction. The measures and actions of the government of this initial period are characterized by spontaneity, incompleteness of the plan, noble thoughts, not brought to implementation.

As the next stage, we can single out the creation of a single new center for the storage of ancient heritage in France at the Napoleon Bonaparte Museum. Collection of the collection was carried out by the right to seize military booty, was of a personal, subjective and extremely chaotic nature.

The restoration period is $1815-1830$ not made significant structural changes.

The direct formation of the state system for the protection of monuments in France was the result of the revolutions of 1789 and

27 Viland K. A. (1906) Okhrana pamyatnikov i rodiny v sovremennykh zakonodatel'stvakh [Protection of monuments and homeland in modern legislation]. Izvestiya Imperatorskoy Arkheologicheskoy Komissii [News of the Imperial Archaeological Commission]. № 20. Pp. 101-150.

28 Novyy frantsuzskiy zakon ob istoricheskikh pamyatnikakh (Utverzhden 31 dekabrya 1913 g.) (1916) [New French Law on Historic Monuments (Approved December 31, 1913)]. Izvestiya imperatorskoy arkheologicheskoy komissii [News of the imperial archaeological commission]. № 60. Pp. 106-116. 
1830. In the second quarter of the XIX century there was a rise in interest in national history, the national past, which was due not only to the natural development of science, but also mainly to political and socio-economic conditions. In France, the desire to restore national unity, the search for national consciousness was carried out on the basis of public policy. We can say that the government and state institutions in many ways not only initiated this activity, but also carried out leadership and control over its implementation. Special state institutions were created to collect, study and preserve monuments of national history, both written and tangible. The government of the country understood that it was impossible to solve the assigned tasks, the help of scientific societies, which began to develop actively at that time, was needed. In France already in the 1830s. a developed network of scientific societies involved in the study of ancient monuments has developed. It should also be noted the importance of the local administration, which contributed not only to the study of antiquities, but also to their preservation, finding sources of funding for these works. As a common problem, we can name the lack of local specialists, which greatly complicated the fulfillment of the tasks set, and above all, the creation of a set of monuments, which was considered as the main measure of their preservation.

The logical conclusion to the long process of forming the foundations of legislative protection of monuments was the adoption of the first comprehensive law on March 30, 1887, the provisions of which were subsequently developed by the "Law on Historical Monuments" of December 31, 1913.

\section{SUMMARY}

Interest in collecting in France arises in parallel with similar processes in other European countries and quickly, by the beginning of the 16th century, is becoming a noticeable phenomenon in the life of French society. Collecting collections turns into a phenomenon that covers literally all segments of the population. The idea of museums in France was formed throughout the eighteenth century, and the French Revolution was the impetus for the creation in France of the foundations of the legislative protection of monuments. The French 
revolutionary government by decree of the National Constituent Assembly of 1790 prohibited the destruction of immovable and movable monuments.

As the next stage, we can single out the creation of a single new center for the storage of ancient heritage in France at the Napoleon Bonaparte Museum. The Napoleon Museum was the last magnificent example of a collection of antiquities in the style of classicism. This museum is at the same time the crown and the end of the whole long revolutionary period in the history of France.

The direct formation of the state system for the protection of monuments in France was the result of the revolutions of 1789 and 1830. In the second quarter of the XIX century there was a rise in interest in national history, the national past, which was due not only to the natural development of science, but also mainly to political and socio-economic conditions. In France, the desire to restore national unity, the search for national consciousness was carried out on the basis of public policy. We can say that the government and state institutions in many ways not only initiated this activity, but also carried out leadership and control over its implementation. Special state institutions were created to collect, study and preserve monuments of national history, both written and tangible. The government of the country understood that it was impossible to solve the assigned tasks, the help of scientific societies, which began to develop actively at that time, was needed. In France already in the 1830s. a developed network of scientific societies involved in the study of ancient monuments has developed.

The completion of the long process of forming the legislative base was the adoption of the first comprehensive law on March 30, 1887, the provisions of which were subsequently developed by the "Law on Historical Monuments" of December 31, 1913.

\section{REFERENCES}

1. Kuklinova I. A. (2001) Muzei Frantsii XIV - XIX vekov [Museums of France of the XIV - XIX centuries]. St. Petersburg: SPbGUKI (in Russian) 
2. Dokumenty istorii Velikoy frantsuzskoy revolyutsii (1990) [Documents of the history of the Great French Revolution]. T. 1. Moscow: MGU, pp. 484-485.

3. David Zh.-L. (1933) Rechi i pis'ma zhivopistsa Lui Davida [Speeches and Letters by the Painter Louis David]. Moscow; Leningrad: Isogiz (in Russian)

4. Mikhaelis A. (1913) Khudozhestvenno-Arkheologicheskie otkrytiya za 100 let [Artistic and archaeological discoveries for 100 years]. Moscow: Izdanie Imperatorskogo Moskovskogo Arkheologicheskogo Instituta Imeni Imperatora Nikolaya II (in Russian)

5. Zhebelev S. A. (1923) Vvedenie v arkheologiyu. Chast' II. Teoriya i praktika arkheologicheskogo znaniya [Introduction to archeology. Part II. Theory and practice of archaeological knowledge]. Petrograd: Nauka i shkola. Pp. 80-81.

6. Kodeks Napoleona (1877) [Codex of Napoleon]. Sobranie grazhdanskikh zakonov guberniy Tsarstva Pol'skogo [Collection of Civil Laws of the Provinces of the Kingdom of Poland]. Pp. 159-164.

7. Malyshev O. O. (2015) Arkheologhichne pravo Franciji: gheneza ta suchasnyj stan [Archeological law of France: genesis and current state]. Chasopys Kyjivsjkogho universytetu prava [Journal of the Kyiv University of Law]. Pp. 33-37.

8. Malyshev O. O. (2018) Romansjka ta ghermansjka tradyciji arkheologhichnogho prava: sproba uzaghaljnennja [Romanesque and Germanic traditions of archaeological law: an attempt to generalize]. Pravova derzhava [Constitutional state]. № 29. Pp. 476-485.

9. Lebedev G. S. (1992) Istoriya otechestvennoy arkheologii [History of Russian Archeology]. St. Petersburg: SPbGU (in Russian)

10.Rytsarev K. V. (1995) Nekotorye tendentsii V zapadnoevropeyskoy arkhitekturnoy restavratsii XIX veka [Some trends in the West European architectural restoration of the XIX century]. Restavratsiya i arkhitekturnaya arkheologiya: Novye materialy i issledovaniya [Restoration and Architectural Archeology: New Materials and Research]. Moscow. № 2. Pp. 4-19.

11.Bazen Zh. (1994) Istoriya istorii iskusstv: Ot Vazari do nashikh dney [History of Art History: From Vasari to the Present]. Moscow: Progress-Kul'tura. (in Russian) 
12.Nikolaeva N. S. (2008) Formirovanie gosudarstvennoy sistemy okhrany pamyatnikov vo vtoroy chetverti XIX veka (sravnitel'nyy analiz: Frantsiya i Rossiya) [Formation of the state system for the protection of monuments in the second quarter of the XIX century (comparative analysis: France and Russia)]. Izvestiya Rossiyskogo gosudarstvennogo pedagogicheskogo universiteta im A. I. Gertsena [Bulletin of the Russian State Pedagogical University named after A. I. Herzen]. № 80. Pp. 261-270.

13.Viland K. A. (1906) Okhrana pamyatnikov i rodiny v sovremennykh zakonodatel'stvakh [Protection of monuments and homeland in modern legislation]. Izvestiya Imperatorskoy Arkheologicheskoy Komissii [News of the Imperial Archaeological Commission]. № 20. Pp. 101-150.

14.Novyy frantsuzskiy zakon ob istoricheskikh pamyatnikakh (Utverzhden 31 dekabrya 1913 g.) (1916) [New French Law on Historic Monuments (Approved December 31, 1913)]. Izvestiya imperatorskoy arkheologicheskoy komissii [News of the imperial archaeological commission]. № 60. Pp. 106-116.

\section{Information about the author: \\ Oleksii Prysiazhniuk,}

PhD (History), Associate Professor at the Department of World History and Methodology of Science, South Ukrainian National Pedagogical University named after K. D. Ushynsky 26, Staroportofrankovskaya str., Odessa, 65020, Ukraine ORCID ID: orcid.org/0000-0003-3727-5350 